\title{
Türkiye'nin İhracatının Katma Değer Dağılımı ve İthal Girdi Bağımlılığı: 2000-2014 Dönemi için Küresel Değer Zinciri Analizi
}

Value Added Distribution of the Turkey's Export and Imported Input Dependency: Global Value Chains Analysis for 2000-2014 period

Huriye ALKIN 1

Geliş tarihi: 19.11.2019, Kabul tarihi: 12.02.2020, Basım tarihi: 10.05.2020

\section{Öz}

Bu çalışmada Dünya Girdi Çıktı Veri Tabanı (WIOD) kullanılarak 2000-2014 yıllarını kapsayan dönemde Türkiye'nin ikili ticaret bağlamında tarım, imalat sanayi ve hizmetler sektöründeki ihracatının yurtiçi katma değer ve yabancı katma değer oranı hesaplanmaktadır. Çalışmanın sonuçları, tarım ve hizmetler sektörü ihracatında yurtiçi katma değer oranının daha yüksek olduğunu ve imalat sanayi ihracatının diğer sektörlere kıyasla daha yüksek yabancı katma değer içerdiğini göstermektedir. 2000-2014 yılları arasında tarım ve hizmetler sektörü ihracatındaki yurtiçi katma değer, \%85 dolaylarında gerçekleşmektedir. İmalat sanayi sektöründe yabancı katma değer oranı, 2000 yılında yaklaşık olarak \%16 iken 2014 yllında $\% 22$ 'dir.

Anahtar Kelimeler: Küresel Değer Zinciri, İhracatta Katma Değer, WIOD, Türkiye

Jel Kodu: F13, F14, F15

\begin{abstract}
This study examines the domestic and foreign value added of Turkey's exports in bilateral trade context in agriculture, manufacturing and services sectors for the period of 2000-2014 utilizing World Input Output Database (WIOD). The empirical results indicate that the domestic value added of the exports in agriculture and services sectors are higher, and manufacturing sectors exports contain higher foreign value added. The domestic value added of the exports in agriculture and services sectors is $85 \%$ approximately between the years of 2000 and 2014 . While the foreign value added of manufacturing sectors is $16 \%$ in 2000 , it is approximately $22 \%$ in 2014 .
\end{abstract}

Key Words: Global V alue Chains, Value Added in Exports, WIOD, Turkey

Jel Codes: F13, F14, F15

\section{Giriş}

Son otuz y1lda üretimdeki parçalanma uluslararası ticaretin yapisını değiştirmekte; ülkeler arasında daha fazla rekabet ve bağımlılık

\footnotetext{
${ }^{1}$ Akdeniz Üniversitesi İ.İ.B.F. İktisat Bölümü, Arş. Gör.

huriyealkin@akdeniz.edu.tr

https://orcid.org/0000-0002-6328-3381
} 
yaratmaktadır. Her ne kadar küreselleşen üretim olgusu yeni olmasa da ve ülkeler her zaman ithal girdiye ihtiyaç duydularsa da bu süreç son otuz yilda ivme kazanmaktadır. Firmaların ve ülkelerin küresel üretim ve küresel dağıtımın parçası oldukları bu ağa, küresel değer zinciri (KDZ) adı verilmektedir. Üretim birçok farklı üretim noktasında aşamalı olarak gerçekleştirilerek nihai ürün elde edilmektedir. KDZ, ülkeler arasında daha fazla rekabet ve bağımlılık yaratmaktadır. Ülkeler, iş ve yatırımları çekmek için rekabet etmelerine karşın diğer ülkelerin talebine, sermayesine ve üretimine daha fazla bağımlı hale gelmektedir. Dış kaynak kullanımının artmasıyla firmalar arasındaki rekabet yatay konumdan (aynı sektörde gerçekleşen rekabet) dikey konuma (uzmanlik gerektiren rekabet) kaymaktadır. Dolayısıyla, firmalar hem birbirlerine rakiptirler hem de birbirleri için temel girdi ve faaliyetlerin kaynağını oluşturmaktadırlar. Üretimdeki parçalanmanın artışı ve ülkelerin birbirlerine bağımlılı̆̆ının artması sonucunda ülkelerin ihracatındaki ithal içerik ve yabancı katma değer artmaktadır. Buna paralel olarak dünya ticaret istatistikleri, bugün dünya ticaretinin üçte ikisinin ara malından oluştuğunu ve bir ülkenin ihracatının yaklaşık olarak dörtte birlik kısmının ithal girdi içerdiğini göstermektedir (Dünya Bankası Türkiye Raporu, 2014; Dünya Kalkınma 2020 Raporu).

KDZ olgusunun yükselişi ile diş ticaretteki katma değer ve dikey uzmanlaşmayı ölçmeye yarayan birçok metot geliştirilmektedir. Geliştirilen metotların kökenleri, Leontief (1936) çalışmasına dayanmaktadır. Leontief ayrıştırma metodunda, ülke ve endüstrilerdeki bir birim çıktının üretimi için gereken ara girdi hesaplanmakta iken bu metot uluslararası gerçekleşen ara girdi akımlarının ayrıştırılmasına imkan vermemektedir. Feenstra ve Hanson (1996) tarafindan geliştirilen ilk ölçüm metodunda, yurtiçi üretimdeki yabancı içerik hesaplanmaktadır. İkinci ölçüm yönteminde, ihracattaki direkt ve dolaylı ithal edilen içerik (dikey uzmanlaşma) hesaplanmaktadır. Bu ayrıştırma yöntemi, Hummels, Ishii ve Yi (2001) tarafindan geliştirilmektedir. Herhangi bir ülkenin, diğer ülkeler tarafindan nihai mal üretiminde ithal girdi olarak kullanılan ve o ülkeye geri dönen ihracatının değerinin hesaplandığ1 ikinci ayrıştırma yöntemi, Daudin, Rifflart ve Schweisguth (2011) tarafından geliştirilmektedir. Üçüncü ölçüm yöntemi, Johnson ve Noguera (2012) tarafından geliştirilmekte ve ihracattaki katma değer hesaplanmaktadır. Dördüncü ölçüm yönteminde, Koopman, Wang ve Wei (2014) ülke bazlı ve Wang, Wei ve Zhu (2013) sektör, ikili ticaret-sektör bazlı çalışmalara imkan veren çalışmalarında ara girdi ticaret verilerinin katma değer ve çift sayım bileşenleri olarak ayrıştırılmasına imkan veren bir ayrıştırma yöntemi geliştirmektedir. Küresel değer zincirinin ölçümü için geliştirilen diğer ölçüm yöntemlerinde, katma değer net olarak ifade edilmeyip ülkelerin brüt ihracatları çifte sayım problemini barındırmaktadır. Bu sebeple Koopman vd. (2014) ve Wang vd. (2013) ayrıştırma yöntemleri, 
ülkelerin küresel değer zincirinde nerede konumlandığını anlamak için ideal ayrıştırma yöntemleridir.

Küresel değer zincirinde yer alma, küresel mal ve hizmetler piyasalarına girme, yabancı sermayeye erişim, teknolojik yenilikleri takip ederek verimlilik ve rekabetçiliği artırmasına olanak sağladığından Dünya Bankası, Dünya Ticaret Örgütü gibi kuruluşların çalışmalarında, gelişmekte olan ülkelerin sanayi politikalarında yer verilmesinin önemine vurgu yapılmaktadır (Eser, 2019:68). Fakat katma değeri düşük, düşük teknolojili ve standart ürün üreten ülkelerin küresel değer zincirinde yer almaları sanayi politikası olarak önerilmemektedir (UNCTAD Ticaret ve Kalkınma Raporu, 2016). Ülkelerin küresel değer zincirinde yer alarak katma değer yaratacak yenilik faaliyetlerine girişerek üretimin katma değeri yüksek aşamalanına geçebilmesi için gerekli alt yap1 ve beşeri sermayeyi temin etmiş olmanın gerekliliğine vurgu yapilmaktadir.

Ülkeyi dışa kapalı hale getiren ithal ikameci sanayileşme stratejisini birakarak 1980 yll itibariyle ihracata dayalı bir sanayileşme stratejisi benimseyen Türkiye, 2000'li y1llarda küreselleşen üretim olgusuna uyum sağlamaktadır. Türkiye'nin küresel ekonomiye entegrasyonun sağlanması ve ihracatta yüksek katma değerin elde edilmesinin önemine, dokuzuncu ve onuncu kalkınma planlarında vurgu yapilmaktadır. Onuncu kalkınma planında, üretimde yurtiçi katma değerin yükseltilmesi ve küresel değer zincirinin daha üst basamaklarına çıkılması için sektör içi verimlilik düzeylerinin artması; rekabet gücünün daha yüksek ve ithalat bağımlılığının daha düşük olduğu üretim yapısının gerekliliğine işaret edilmektedir. Küresel değer zincirinde daha üst basamaklarda yer alınmasının önemine vurgu yapıldığ1 üzere, Türkiye'nin küresel yeni iş bölümünde yaşanan dönüşüme uyum sağlayıp sağlamadığı Türkiye ekonomisi için önem arz etmektedir.

Türkiye'nin küresel değer zincirindeki konumunun araştırıldı̆̆1 diğer çalışmalardan farklı olarak, bu çalışmada katma değerin çifte sayım probleminden arındırılarak net olarak hesaplandığı Wang, Wei ve Zhu (2013) ayrıştırma metodu kullanılmaktadır. Diğer çalışmalardan farklılığı oluşturan bir başka husus, analizin 56 ayrı sektör için yapılmasıdır. İncelenen dönem itibariyle daha güncel olan analizin, ihracatın sektör-ülke bazında ayrıştırılarak gerçekleştirilmesi bu çalışmanın diğer bir farkını oluşturmaktadir.

Dünya Girdi Çıktı Veri Tabanı (World Input Output Database-WIOD) kullanılarak 56 ayrı sektör ve 2000-2014 dönemleri için yapılan bu çalışmada, Türkiye'den 43 ülkeye yapılan (28 Avrupa Birliği ülkesi; diğer 14 başlica ülke ve diğer dünya ülkeleri) ikili ihracat, 16 ayrı bileşene ayrıştırılarak sektörel ihracattaki yabancı katma değer ve yurtiçi katma değer analiz edilmektedir. Yapılan bu çalışma ile Türkiye'nin hangi sektörlerde nihai mal ihracatçısı hangi sektörlerde ara mal ihracatçısı olduğu; yapılan ihracatın ne kadarlık 
kısmının diğer ülkelerin ihracatları aracıllğıyla ülkeye geri dönerek kullanıldığı; nihai ve ara mal ihracatında ne kadar yabancı katma değerin kullanıldığı ayrıntılı bir şekilde incelenmektedir.

Çalışmanın birinci bölümünde Wang, Wei ve Zhu (2013) ayrıştırma yöntemi, ikinci bölümde Türkiye'nin uluslararas1 ticaret ve küresel değer zincirindeki konumu, üçüncü bölümde veri ve metodoloji ve son bölümde de sonuç ve değerlendirme yer almaktadır.

\section{Wang, Wei ve Zhu (2013) Ayrıştırma Yöntemi}

Brüt olarak açıklanan ve hem ara girdi hem de nihai çıtııı içeren, tüm resmi dış ticaret istatistiklerinde uluslararası sınırlardan birden fazla sayıda geçen ara malın değeri çift sayılmaktadır. Günümüzde üretimin farklı aşamalarını farklı ülkelerin gerçekleştirilmesi ve ara girdilerin uluslararası sınırlardan birden çok kez geçmesi sebebi ile geleneksel dış ticaret istatistikleri güvenilirliğini yitirmektedir. Dış ticaret istatistiklerindeki bu elverişsizliğin önüne geçmek için Koopman, Wang ve Wei (2014), brüt ihracatın katma değer ve çifte sayım bileşenlerinden oluşan bir ayrıştırma yöntemi geliştirmektedir. Dokuz ayrı alt bileşenden oluşan bu ayrıştırma metodu dört ayrı büyük başlık altında toplanmaktadır. İlki, ihracattaki yurtiçi katma değerdir. Bu katma değer, yurtdışında tüketilmektedir. İkincisi, önce ihraç edilen ardından ülkeye geri dönen yurtiçi katma değerdir. Bu katma değer, ihracattaki katma değer içerisinde yer almayıp ihracatçı ülkenin gelirinin bir kısmını oluşturmaktadır. Üçüncüsü, ihracatçı ülkenin ihracat yapmak için kullandığ1 yabancı katma değerdir. Dördüncü başlık ise çifte sayım bileşeni olup bu bileşen ile uluslararası sınırlarda çok kez sayılan ara mal ticareti ifade edilmek istenmektedir. Koopman vd. (2014) ayrıştırma metodu, ülke düzeyindeki ihracat verileri için geliştirilmektedir. Ülke düzeyindeki ihracat verileri için geliştirilen bu ayrıştırma metoduna alternatif olarak Wang, Wei ve Zhu (2013), sektör, ikili ticaret ya da ikili ticaret-sektör düzeyinde çalışmalara imkan veren ayrıştırma metodu geliştirmektedir. Wang vd. (2013) metodunun, Koopman vd. (2014) ayrıştırma metodundan bir farkı da geri ve ileri endüstri bağ ayrımının yapılmasıdır. Geri ve ileri bağ ayrımı ile ikili ticaret-sektör düzeyinde brüt ara girdi ticaret akımlarının nihai olarak tüketimlerinin ayrıştırılması mümkün olmaktadır.

Wang vd. (2013), dış ticarette katma değer ya da dikey uzmanlaşma ile ilgili ayrıştırma metotlarının kökenlerinin dayandığı Leontief (1936) çalışmasından faydalanarak s ülkesinden $r$ ülkesine yaptığ brüt ihracatı², (1) numaralı denklemde yer aldığı gibi ayrıştırmaktadır.

$$
\begin{aligned}
& E^{s r}=\left(V^{s} B^{s s}\right)^{T} \# Y^{s r}+\left(V^{s} L^{s s}\right)^{T} \#\left(A^{s r} B^{r r} Y^{r r}\right) \\
& +\left(V^{s} L^{s s}\right)^{T} \#\left[A^{s r} \sum_{t \neq s, r}^{G} B^{r t} Y^{t t}+A^{s r} B^{r r} \sum_{t \neq s, r}^{G} Y^{r t}+A^{s r} \sum_{t \neq s, r}^{G} B^{r t} \sum_{u \neq s, t}^{G} Y^{t u}\right]
\end{aligned}
$$

2 Wang vd. (2013) ayrıştırma yönteminin ayrıntıları EK'de yer almaktadır. 


$$
\begin{aligned}
& +\left(V^{s} L^{s s}\right)^{T} \#\left[A^{s r} B^{r r} Y^{r s}+A^{s r} \sum_{t \neq s, r}^{G} B^{r t} Y^{t s}+A^{s r} B^{r s} Y^{s s}\right] \\
& \left.+\left[\left(V^{s} L^{s s}\right)^{T} \# A^{s r} B^{r s} \sum_{t \neq s}^{G} Y^{s t}\right)+\left(V^{s} L^{s s} \sum_{t \neq s}^{G} A^{s t} B^{t s}\right)^{T} \#\left(A^{s r} X^{r}\right)\right] \\
& +\left[\left(V^{r} B^{r s}\right)^{T} \# Y^{s r}+\left(\sum_{t \neq s, r}^{G} V^{t} B^{t s}\right)^{T} \# Y^{s r}\right]
\end{aligned}
$$

Denklem, 16 bileșen ve 8 kategoriden oluşmaktadır. Denklemin ilk kategorisi, nihai mal ihracatındaki yurtiçi katma değeri göstermektedir. İkinci kategori, $s$ ülkesinin $r$ ülkesine, $r$ ülkesinde yurtiçi nihai mal olarak kullanılmak üzere, ara mal ihracatını ifade etmektedir. Üçüncü kategoride s ülkesinden $\mathrm{r}$ ülkesine gönderilen ara malı ihracatı gösterilmekte olup bu ara mal, r ülkesi tarafından s ülkesi dişındaki diğer ülkelere ihracat yapmak için kullanılmaktadır. Üçüncü kategorinin ilk bileşeni s ülkesinden $\mathrm{r}$ ülkesine yapılan ara malı ihracattaki katma değeri göstermekte olup bu ara mal ihracatı, r ülkesi tarafindan üçüncü ülkelere ara malı ihracatı yapmak amacıyla kullanılmaktadır. Üçüncü kategorinin ikinci bileşeni s ülkesinden $r$ ülkesine yapılan ara malı ihracatı göstermekte olup bu ara mal ihracatı, r ülkesi tarafından üçüncü ülkelere nihai mal ihracatı yapmak amacıyla kullanılmaktadır. Üçüncü kategorinin üçüncü bileşeninde $s$ ülkesinin $r$ ülkesine ara malı ihracatı gösterilmekte olup bu ara malı, r ülkesi tarafından $\mathrm{t}$ ülkesine ara malı ihracatı yapmak için kullanılmaktadır. T ülkesine gönderilen bu ara mal, s ve t ülkesi dişındaki ülkelere nihai mal ihracatı yapmak üzere kullanılmaktadır. İlk üç kategorinin toplamı, s ülkesinin r ülkesine yaptığı brüt ihracattaki yurtiçi katma değeri göstermektedir. Brüt ihracattaki katma değer, geri endüstri bağına tabi olan brüt ihracat akımları ile ilişkilendirilmektedir.

Dördüncü kategori, s ülkesi tarafından ihracatı yapılan ve ardından ülkeye geri dönen ara malı ihracatındaki yurtiçi katma değeri ifade etmektedir. Bu kategorinin ilk bileşeni, $r$ ülkesinden yapılan nihai mal ithalatında geri dönen kısmın katma değerini, ikinci bileşen, $\mathrm{t}$ ülkesinden yapılan nihai mal ithalatında geri dönen kısmın katma değerini ve üçüncü bileşen ise yurtiçinde nihai mal olarak kullanılmak üzere yapılan ara malı ithalatı içerisinde yer alan yurtiçi katma değeri göstermektedir. İlk dört kategori, s ülkesinde yer alan bütün sektörlerin $\mathrm{r}$ ülkesine olan brüt ihracatlarındaki yurtiçi katma değeri göstermektedir.

Beşinci kategori, yurtiçi çifte sayım bileşenini tanımlamaktadır. İlk bileşen, s ülkesinin $r$ ülkesine yaptığı ara mal ihracatının s ülkesine nihai mal ihracatı yapmak üzere ara malı ithalatı olarak geri dönen kısmında yer alan yurtiçi katma değeri göstermektedir. Bu bileşen, nihai mal ihracatındaki katma değerin bir kısmını oluşturmaktadır ve (1) numaralı denklemin ilk bileşeninde sayılmış bulunmaktadır. Ara malının yurtdışına gidip ardından tekrar ülkeye geri dönmesi sebebi ile çift sayım olarak ifade edilmektedir. İkinci bileşen, s ülkesinin $r$ ülkesine yaptığı ara mal ihracatının s ülkesine ara mal ihracatı yapılmak üzere ara malı ithalatı olarak geri dönen kısmında yer 
alan yurtiçi katma değeri göstermektedir. Ara malı ihracatı yapmak üzere ara malının yurtdışına gidip ardından tekrar ülkeye geri dönmesi sebebi ile çift sayım olarak ifade edilmektedir.

Altıncı kategorinin ilk bileşeni, s ülkesinin nihai mal ihracatında $\mathrm{r}$ ülkesine ait yabancı katma değeri; ikinci bileşen, s ülkesinin nihai mal ihracatında t ülkesine ait yabancı katma değeri göstermektedir.

Yedinci kategorinin ilk bileşeni, s ülkesinin $\mathrm{r}$ ülkesine, $\mathrm{r}$ ülkesinin yurtiçi nihai mal üretmesi için, yaptığı ara malı ihracatında $\mathrm{r}$ ülkesine ait olan katma değeri göstermektedir. İkinci bileşen, s ülkesinin $r$ ülkesine, $r$ ülkesinin yurtiçi nihai mal üretmesi için, yaptığı ara malı ihracatında t ülkesine ait olan katma değeri göstermektedir. Altınc1 ve yedinci kategori toplamı, s ülkesindeki sektörlerin $r$ ülkesine yaptığ1 ihracattaki toplam yabanc1 katma değeri göstermektedir.

Sekizinci kategori, s ülkesinin ihracatında çift sayılan yabancı katma değeri göstermektedir. İlk bileşen, direkt ithalatçı olan r ülkesinin ihracatını yapmak için s ülkesinden yapmış olduğu ara malı ithalatındaki katma değeri göstermektedir. Bu bileşen, s ülkesinin ihracatında $\mathrm{r}$ ülkesinin çift sayılan katma değerini ifade emektedir. İkinci bileşen, r ülkesinin ihracat yapmak için s ülkesinden yapmış olduğu ithalatın içeriğinde $t$ ülkesine ait olan katma değeri göstermekte olup bu bileşen, s ülkesinin ihracatında $t$ ülkesinin çift sayılan katma değerini ifade etmektedir.

(1) numaralı denklemde yer verilen 16 bileşen ve 8 kategori, s ülkesinden r ülkesine yapılan ihracatı farklı katma değer ve çift sayılan bileşenlere ayırmaktadır. Katma değerlerin ve çift sayılan bileşenlerin toplamı sektör düzeyinde yapılan ikili ihracatın toplamına eşittir. 1 numaralı şekilde Wang vd. (2013) tarafından geliştirilen bu ayrıştırma yöntemine yer verilmektedir. 


\section{Şekil 1. Brüt Ticaret Ayrıştırılması}

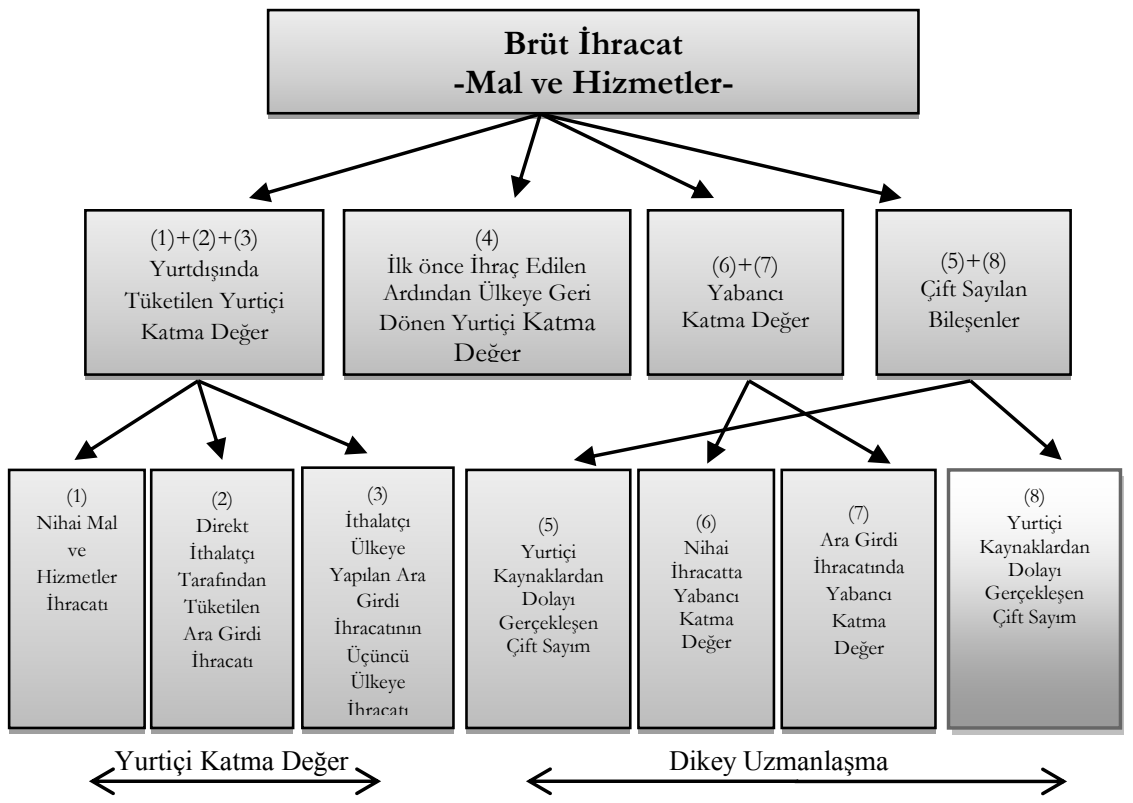

Kaynak: Wang vd. (2013)

1 numaralı şekilde yer alan dikey uzmanlaşma 5, 6, 7 ve 8 numaralı kategorinin toplamına eşittir. Dikey uzmanlaşma, çift sayılan bileşenleri de içermektedir. Dikey uzmanlaşma kavramı ilk olarak Hummels, Ishii ve Yi (2001) tarafindan ortaya atılmakla birlikte şekilde yer alan dikey uzmanlaşma kavram1, Wang vd. (2013) tarafindan ara malın ticaretinde birden fazla ülkenin yer alacağ1 şekilde genişletilmektedir.

Tablo 1. Wang vd. (2013) Ayrıştırma Yönteminde Yer Alan Bileşenlerin Tanımları

\begin{tabular}{|c|c|c|c|}
\hline Kategori & Bileşen & & $\begin{array}{c}\text { Tanim } \\
\end{array}$ \\
\hline 1 & 1 & $\left(V^{s} B^{s S}\right)^{T} \# Y^{s r}$ & $\begin{array}{l}\text { s ülkesinin nihai ihracatındaki yurtiçi katma } \\
\text { değer }\end{array}$ \\
\hline 2 & 2 & $\left(V^{s} L^{s s}\right)^{T} \#\left(A^{s r} B^{r r} Y^{r r}\right)$ & $\begin{array}{c}\text { s ülkesi tarafindan direkt ithalatçıya gönderilip } \\
\text { orada tüketilen ara girdi ihracatındaki yurtiçi } \\
\text { katma değer }\end{array}$ \\
\hline 3 & 3 & $\left(V^{s} L^{s s}\right)^{T} \# A^{s r} \sum_{t \neq s, r}^{G} B^{r t} Y^{t t}$ & $\begin{array}{l}\text { s ülkesi tarafindan r ülkesine gönderilen ara girdi } \\
\text { ihracatındaki yurtiçi katma değer (ardından } \\
\text { üçüncü ülkelerin yurtiçi nihai kullanım üretimi } \\
\text { yapması için direkt ithalatçı tarafından ara girdi } \\
\text { ihracatı yapılır) }\end{array}$ \\
\hline 3 & 4 & $\left(V^{s} L^{s s}\right)^{T} \# A^{s r} B^{r r} \sum_{t \neq s, r}^{G} Y^{r t}$ & $\begin{array}{c}\text { s ülkesi tarafından r ülkesine gönderilen ara girdi } \\
\text { ihracatındaki yurtiçi katma değer (ardından } \\
\text { direkt ithalatçı tarafından üçüncü ülkelere nihai } \\
\text { ihracat yapılır) }\end{array}$ \\
\hline 3 & 5 & $\left(V^{s} L^{s s}\right)^{T} \# A^{s r} \sum_{t \neq s, r}^{G} B^{r t} \sum_{u \neq s, t}^{G} Y^{t u}$ & $\begin{array}{c}\text { s ülkesi tarafindan r ülkesine gönderilen ara girdi } \\
\text { ihracatındaki yurtiçi katma değer (ardından } \\
\text { direkt ithalatçı tarafından üçüncü ülkelere ara } \\
\text { girdi ihracatı yapıllır) }\end{array}$ \\
\hline 4 & 6 & $\left(V^{s} L^{s s}\right)^{T} \# A^{s r} B^{r r} Y^{r s}$ & $\begin{array}{l}\text { s ülkesinin r ülkesinden yaptığı nihai ithalattaki } \\
\text { geri dönen yurtiçi katma değer }\end{array}$ \\
\hline
\end{tabular}




\begin{tabular}{|c|c|c|c|}
\hline 4 & 7 & $\left(V^{s} L^{S s}\right)^{T} \# A^{s r} \sum_{t \neq s, r}^{G} B^{r t} Y^{t s}$ & $\begin{array}{l}\text { s ülkesi tarafindan t ülkesi vasıtasıyla yapılan } \\
\text { nihai ithalatta geri dönen yurtiçi katma değer }\end{array}$ \\
\hline 4 & 8 & $\left(V^{s} L^{s s}\right)^{T} \# A^{s r} B^{r s} Y^{s S}$ & $\begin{array}{l}\text { s ülkesinin ara malı ithalatt ile geri dönen yurtiçi } \\
\text { katma değer }\end{array}$ \\
\hline 5 & 9 & $\left(V^{s} L^{s s}\right)^{T} \# A^{s r} B^{r s} \sum_{t \neq s}^{G} Y^{s t}$ & $\begin{array}{l}\text { s ülkesinin nihai ihracat üretimi yapmasından } \\
\text { kaynaklı olarak çift sayılan katma değer }\end{array}$ \\
\hline 5 & 10 & $\left(V^{s} L^{s s} \sum_{t \neq s}^{G} A^{s t} B^{t s}\right)^{T} \#\left(A^{s r} X^{r}\right)$ & $\begin{array}{c}\mathrm{s} \text { ülkesinin ara girdi ihracatt için üretim } \\
\text { yapmasından kaynaklı olarak çift sayllan katma } \\
\text { değer }\end{array}$ \\
\hline 6 & 11 & $\left(V^{r} B^{r s}\right)^{T} \# Y^{s r}$ & $\begin{array}{l}\text { s ülkesinin nihai ihracatında } \mathrm{r} \text { ülkesine ait olan } \\
\text { katma değer }\end{array}$ \\
\hline 6 & 12 & $\left(\sum_{t \neq s, r}^{G} V^{t} B^{t s}\right)^{T} \# Y^{s r}$ & $\begin{array}{c}\text { s ülkesinin } \mathrm{r} \text { ülkesine nihai ihracatında t ülkesine } \\
\text { ait olan katma değer }\end{array}$ \\
\hline 7 & 13 & $\left(V^{r} B^{r s}\right)^{T} \#\left(A^{s r} L^{r r} Y^{r r}\right)$ & $\begin{array}{l}\text { s ülkesinin ara girdi ihracatında r ülkesine ait } \\
\text { olan katma değer }\end{array}$ \\
\hline 7 & 14 & $\left.\sum_{t \neq s, r}^{G} V^{t} B^{t s}\right)^{T} \#\left(A^{s r} L^{r r} Y^{r r}\right)$ & $\begin{array}{l}\mathrm{s} \text { ülkesinin } \mathrm{r} \text { ülkesine ara girdi ihracatında } \mathrm{t} \\
\text { ülkesine ait olan katma değer }\end{array}$ \\
\hline 8 & 15 & $\left(V^{r} B^{r s}\right)^{T} \#\left(A^{s r} L^{r r} E^{r^{*}}\right)$ & $\begin{array}{l}\text { r ülkesine ait olup s ülkesinin ihracatında çift } \\
\text { sayılan katma değer }\end{array}$ \\
\hline 8 & 16 & $\left(\sum_{t \neq s, r}^{G} V^{t} B^{t s}\right)^{T} \#\left(A^{s r} L^{r r} E^{r^{*}}\right)$ & $\begin{array}{l}\text { t ülkesine ait olup s ülkesinin ihracatında çift } \\
\text { sayılan katma değer }\end{array}$ \\
\hline
\end{tabular}

Kaynak: Wang vd. (2013)

\section{Türkiye'nin Uluslararası Ticaret ve Küresel Değer Zincirindeki Konumu}

Türkiye, küresel ortamın elverişliliği, yurtiçindeki yapısal reformların gelişimi ve üretken firmaların varllğı sayesinde 2002 yllında 36 milyar dolar olan ihracatını 2012'de 150 milyar dolara çıkarmaktadır. Ayrıca, hem ihracat pazarlarını hem de ihracat ürünlerinin çeşitliliğini artırarak 2001 ylında 90 ülkeye ihracat yaparken 2014 yllında 137 ülkeye ihracat yaparak eriştiği pazarları artırmaktadır. Küresel açıdan daha rekabetçi konuma gelen Türkiye, 2002'de küresel ithalatın yüzde 0.55 'ini oluştururken 2012 'de bu oran 0.82 seviyelerinde gerçekleşmektedir. Her ne kadar ihracatta artış yaşansa da bu artış gelir artı̧ıııda önemli bir rol oynayamamaktadır. İhracatın gayrisafi yurtiçi hasılaya oranı 1998-2000 döneminde yüzde 20 iken bu oran 20092011 döneminde yüzde 23 seviyesine çıkarak benzer gelire sahip ülkelerden daha az artış oranı gerçekleşmektedir (Dünya Bankası Türkiye Raporu, 2014).

Nominal ihracat büyümesinin yanı sıra asıl önemli olan husus, katma değerdeki büyüme, ihracattaki içerik, üretilen ürünlerin niteliği ve küresel değer zincirinde ülkenin nerede konumlandığıdır. Dünya Bankası Türkiye Raporu (2014), Türkiye'nin benzer kalkınma düzeyine sahip ülkelerle kıyaslandığında küresel talebi yavaş büyüyen, orta teknolojiye sahip sektörlerde yoğunlaştığını göstermektedir. Ayrıca, rapor, hammaddelerin üretildiği, araştırma ve tasarım gibi faaliyetlerin yapıldığı üretimin ilk 
aşamasında ya da nihai ürünlerin montajının yapıldığı son aşamada değil değer zincirinin ortasında standart emek yoğun imalat işlerine odaklanıldığını belgelemektedir. Her ne kadar Türkiye, orta teknolojiye sahip sektörlerde yoğunlaşsa da ortalamadan daha uzun değer zincirlerine sahip ekonomik faaliyetlerde güçlü olması ve ticaret maliyetlerinin düşük olması, KDZ'de yükselmesi için avantajının olduğunu gösteren unsurlardır (Dünya Bankası, 2014).

Taymaz (2011), Saygllı vd. (2014), Özmen (2015) ve Gündoğdu ve Saraçoğlu (2016) çalışması, Türkiye'nin küresel değer zincirindeki konumunu araştıran çalışmalara örnek olarak verilebilir. Taymaz (2011), 1980 sonrasına odaklandığ1 çalışmasında, üretim sürecine göre dikey parçalanmış bir yap1 altında 34 ayrı sektörün diş ticaretteki değişimlerini analiz etmektedir. Çalışmanın bulguları, Türkiye'de 1970’lerde tarımsal ürün ağırlıklı sektörlerde, 1980'lerde tekstil ve giyim gibi emek yoğun sektörlerde ve 1990'ların ortalarından itibaren de orta teknoloji olarak tanımlanabilecek makine ve otomotiv gibi ürünlerde uzmanlaşıldığına işaret etmektedir. Türkiye'nin makina ve kara taşıtları gibi orta-teknolojili ürünlerde rekabetçi olmasının olumlu bir gelişme olmakla birlikte, bu ürünlerin üretiminde daha standart teknoloji kullanan aşamalarda uzmanlaşılması sebebiyle uluslararası ekonomi içindeki konumunun güçlenmesine katk1 yapmaktan uzak olduğuna vurgu yapılmaktadır. İmalat sanayi sektöründeki 145 sanayi firmasına uygulanan anket ve yüz yüze görüşmeler yoluyla derlenen bilgilerin kullanıldığı çalışmalarında Saygılı vd. (2014), 1979 yllında \%7.6 seviyesinde gerçekleşen dolaylı ve dolaysız ithalat gereği katsayılarının 2002 yılında $\% 15.73$ seviyesinde gerçekleştĭgine işaret etmektedirler. İmalat sanayi sektöründe bu katsayilar \%11.6 seviyesinden \%26.7 seviyesine yükselmektedir. OECD-TIVA verilerini kullanarak imalat sanayi sektöründeki yurtiçi katma değeri hesaplayan Özmen (2015), bu oranın 1995 'te $\% 89$, 2000'de \%85 ve 2008 'de \%74 olarak gerçekleştiği sonucuna ulaşmaktadır. Gündoğdu ve Saraçoğlu (2016), Türkiye'nin küresel değer zincirinde nerede konumlandığını analiz etmek için WIOD verilerini kullanarak 1995-2011 yıllarını kapsayan dönemde Türkiye'nin dikey uzmanlaşmasının nasıl değiştiğini hesapladıkları çalışmalarında Türkiye'nin dikey uzmanlaşmasında Almanya, Çin, İtalya ve Fransa'nın önem arz ettiğine ve dikey uzmanlaşmanın 1995 ve 2011 yılları arasında arttı̆̆ sonucuna yer vermektedir.

\section{Veri ve Metodoloji}

Bu çalışmada WIOD veri tabanı kullanılarak 2000-2014 yıllarını kapsayan dönemde ekonominin bütününü kapsayan 56 ayr1 sektörde Türkiye'nin küresel değer zincirinde nerede konumlandığ 1 araştırılmaktadır. Küresel değer zinciri ölçüm yöntemi olarak Wang vd. (2013) ayrıştırma yöntemi 
kullanılmaktadır. Bu ayrıştırma yöntemi ile Türkiye'den 43 ülkeye yapılan ihracat 8 ayrı kategori ve 16 ayrı bileşene ayrıştırılmaktadır.

Grafiklerde Türkiye'nin en çok ihracat yaptığ1 6 ülke ve 12 sektöre yer verilmektedir. Türkiye'nin ihracatında en yüksek payı olan ülkeler Almanya, Fransa, Birleşik Krallık, İtalya, Rusya ve Amerika Birleşik Devletleri'dir. En çok ihracat yapılan sektörler ise tarım, g1da, tekstil ve deri, kimyasal ürünler, kauçuk ve plastik ürünler, metalik olmayan mineral ürünler, ana metal, makine ve ekipman, motorlu taşıtlar, toptan ticaret, perakende ticaret ve kara taşımacılığıdır.

Sektörlerin ihracattaki yüzdelik payları, 1 numaralı grafikte gösterilmektedir. İhracatta en yüksek pay, gayrisafi yurtiçi hasılanın yaklaşık olarak yüzde 15'ini açıklayan imalat sanayi sektörünün olup, yıllar içerisinde bu sektörün ihracattaki payı artış göstermektedir. Gelirdeki payı \%60 civarında olan hizmetler sektörünün ihracattaki payı y1llar içerisinde düşmüştür. Ziemann ve Guerard (2017:7) çalışmasında da Türkiye'nin 2000 yilindan itibaren yüksek ihracat performansının imalat sanayi kaynaklı olduğu ve hizmetler sektörünün ihracat payının düşmekte olduğu vurgulanmaktadır (Ziemann ve Guerard, 2017:7).

\section{Grafik 1. Sektörlerin Toplam İhracattaki Payı (\%)}

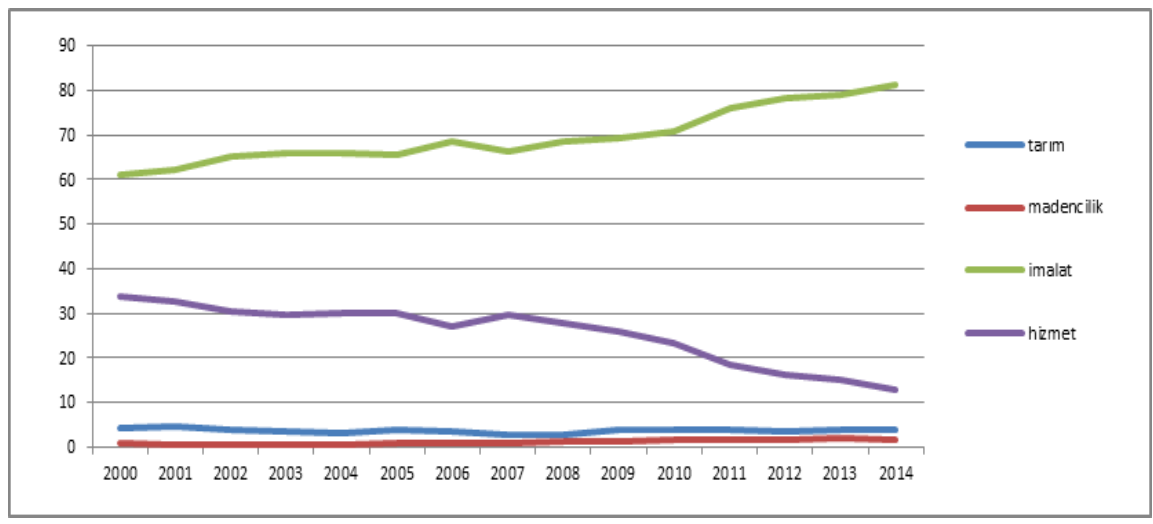

Kaynak: WIOD (2016) kullanılarak yazar tarafindan oluşturulmuştur.

Sektörlerin ihracatındaki yabancı katma değerin yüzdelik payı, 2 numaralı grafikte gösterilmektedir. Yabanc1 katma değerin en çok yer aldığı sektör, imalat sanayi sektörüdür. Beklendiği üzere küresel kriz döneminde üretimdeki düşüşle paralel olarak yabanc1 katma değerde azalma gerçekleşmektedir. 


\section{Grafik 2. Sektörlerin İhracatındaki Yabancı Katma Değer (\%)}

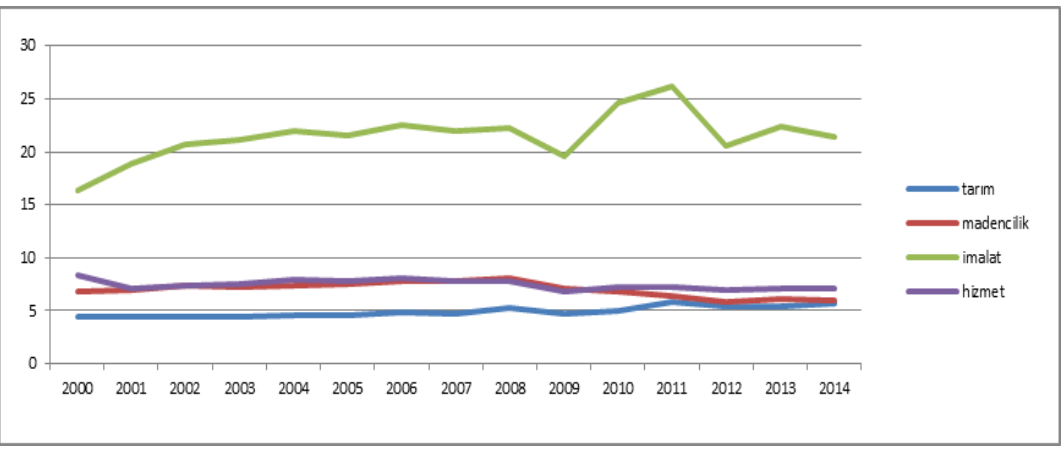

Kaynak: WIOD (2016) kullanılarak yazar tarafindan oluşturulmuştur.

Sektörlerin ihracatındaki yurtiçi katma değerin yüzdelik payı, 3 numaralı grafikte gösterilmektedir. Yurtiçi katma değerin en az olduğu sektör, imalat sanayi sektörüdür. Diğer üç ana sektörde yurtiçi katma değer, 15 yıllık süreçte çok değişiklik göstermemekte iken; imalat sanayi sektörü ihracatında yer alan yurtiçi katma değerde yüksek oranda azalma gerçekleşmektedir.

\section{Grafik 3. Sektörlerin İhracatındaki Yurtiçi Katma Değer (\%)}

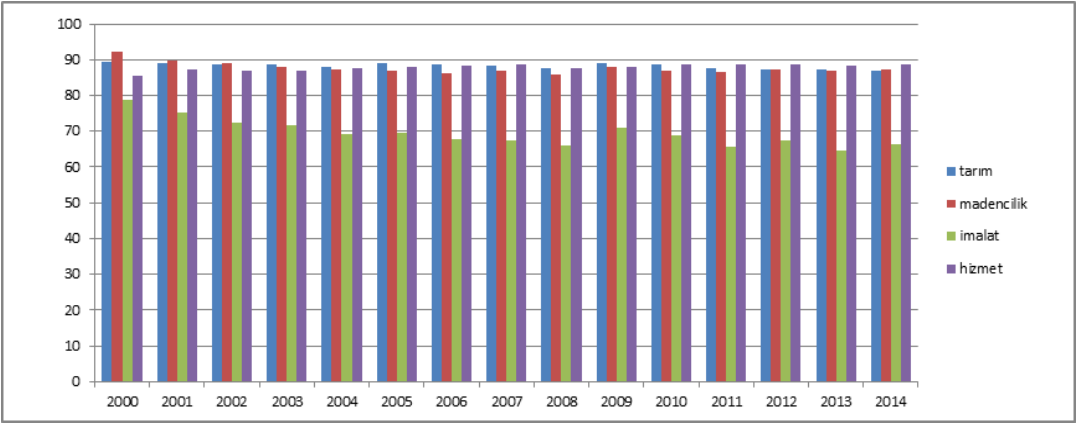

Kaynak: WIOD (2016) kullanılarak yazar tarafindan oluşturulmuştur.

Aşağıdaki grafiklerde Türkiye'nin en çok ihracat yaptığ1 6 ülke ve 12 sektörün sonuçlarına yer verilmektedir. Gösterilen bütün grafiklerde dikey eksen, söz konusu olan kategori ya da bileşenin sektör ihracatındaki yüzdelik payını vermektedir.

Wang vd. (2013) tarafindan geliştirilen ayrıştırma metodunda yer alan 1, 2, 3, 4 ve 5 numaralı bileşenlerin ya da ilk üç kategorinin toplanmasıyla, brüt ihracattaki yurtiçi katma değer elde edilmektedir. 4 numaralı grafikte, sektör ihracatlarındaki yurtiçi katma değerin ülkelere göre çok az farklılık gösterdiği sonucuna ulaşılmaktadır. Yurtiçi katma değerin en yüksek olduğu sektörler, tarım ve hizmetler sektörü olup en düşük yurtiçi katma değerin olduğu sektör, imalat sanayi sektörüdür. Akkoyunlu vd. (2018) çalışmasına paralel 
olarak, 2000 yllına kıyasla 2014 yılında özellikle imalat sanayi olmak üzere hemen hemen bütün sektör ihracatları daha düşük yurtiçi katma değer içermektedir.

\section{Grafik 4. İhracatta Yurtiçi Katma Değer (\%)}

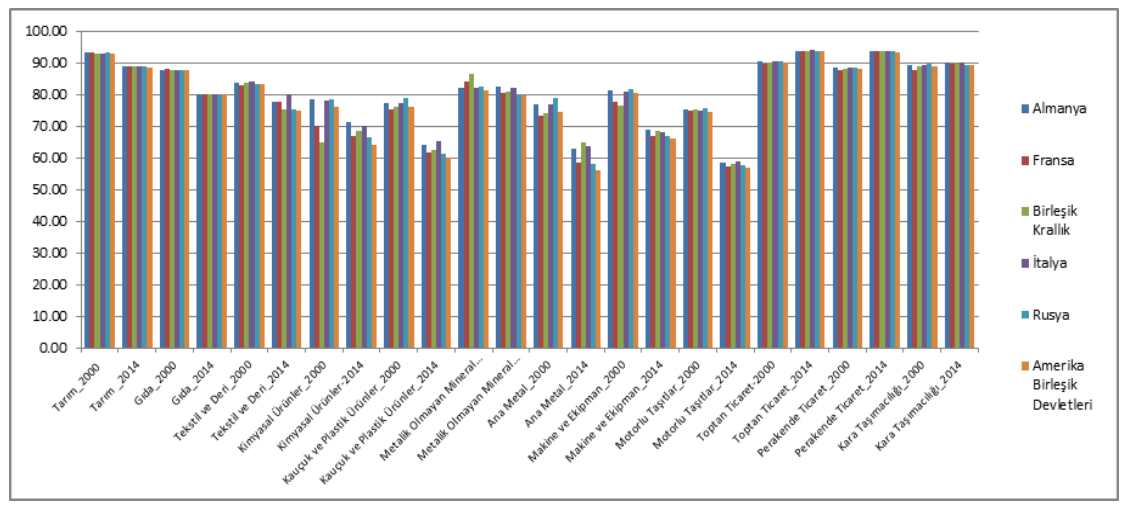

Kaynak: WIOD (2016) kullanılarak yazar tarafindan oluşturulmuştur.

Geliştirilen ayrıştırma metodu kullanılarak 11, 12, 13 ve 14 numaralı terimler bileşenler ya da 6 ve 7 numaralı kategoriler toplanarak brüt ihracattaki yabancı katma değer elde edilmektedir. 5 numaralı grafik, tarım ve g1da sektörü dişındaki bütün sektörlerde yabancı katma değerin ülkelere göre farklılaştığını göstermektedir. Ziemann ve Guerard (2017:9) çalışmasına paralel olarak, Türkiye'nin ihracatındaki ithal girdilerin oranı (geri katılım) imalat sanayi sektöründe güçlü iken hizmetler sektöründe görece daha düşük gerçekleşmektedir. Diğer sektörlere kıyasla daha yüksek yabancı katma değer içermekte olan imalat sanayi sektöründe en yüksek yabanc1 katma değerin bulunduğu alt sektörler, motorlu taşıtlar, makine ve ekipman, kauçuk ve plastik ürünler sektörleridir. Türkiye’in karşılaştırmalı üstünlük geliştirdiği tekstil sektörü ihracatı, diğer imalat sektörü ihracatlarına göre daha az yabanc1 katma değer içermekte olup bu oran OECD Raporu (2017)'nda olduğu gibi ortalama olarak \%20'dir.

Ülkeler arasında karşılaştırma yapıldığında; Amerika Birleşik Devletleri'ne yapılan ihracatın, diğer ülkelere yapılan ihracata kıyasla daha çok yabancı katma değer içerdiği sonucuna ulaşılmaktadır. 


\section{Grafik 5. İhracatta Yabancı Katma Değer (\%)}

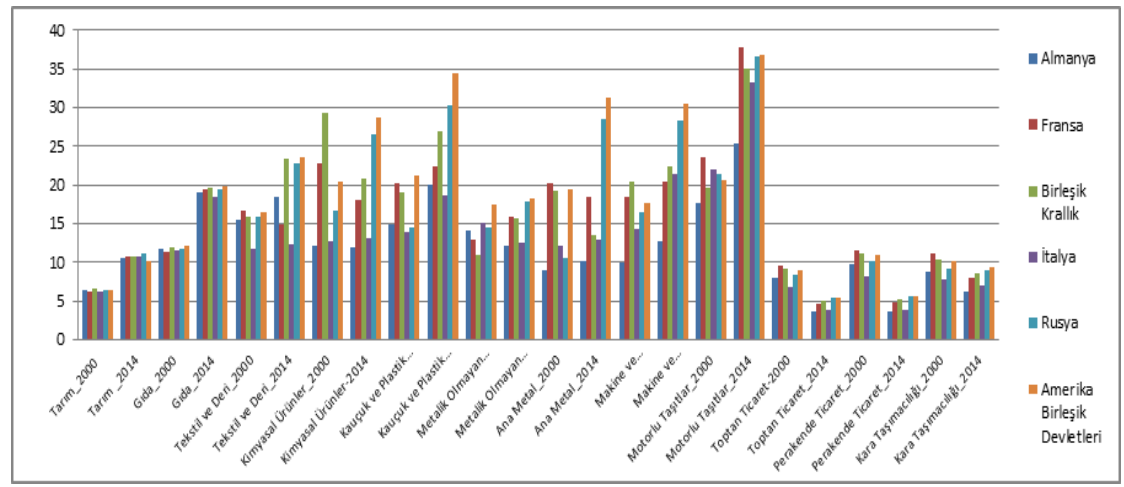

Kaynak: WIOD (2016) kullanılarak yazar tarafından oluşturulmuştur.

Wang vd. (2013:23-28), bir ülkenin nihai mal ihracatına k1yasla ara mal ihracatındaki yurtiçi katma değerin daha yüksek olması halinde, o ülkenin küresel üretim zincirinin daha üst basamaklarında konumlanacağını vurgulamaktadır. Nihai mal ihracatındaki yurtiçi katma değerin ara mal ihracatındaki yurtiçi katma değerden daha yüksek olduğu durumda da o ülke küresel üretim zincirinin daha alt basamaklarında yer alacaktır.

Çalışmada, bir sektörün ara mal ihracatının nihai mal ihracatından daha yüksek olması durumunda o sektör, ara mal ihracatçısı; nihai mal ihracatının ara mal ihracatından daha yüksek olması durumunda da nihai mal ihracatçısı olarak adlandırılacaktır. 6 numaralı grafikte, 2000 yılında 'Türkiye'nin tarım, g1da, tekstil ve deri, makine ve ekipman, motorlu satışlar, toptan ve perakende ticaret ve kara taşımacılığında nihai mal ihracatçısı; kimyasal ürünler, kauçuk ve plastik ürünler, metalik olmayan mineral, ana metal imalat sanayi sektörlerinde ara mal ihracatçısı olduğu görülmektedir. Dolayısıyla Türkiye, kimyasal ürünler, kauçuk ve plastik ürünler, metalik olmayan mineral ve ana metal imalat sanayi sektörlerinde diğer sektörlere kiyasla küresel değer zincirinin daha üst basamaklarında konumlanmaktadır. 
Grafik 6. İhracatta Ara Mal-Nihai Mal Ayrımı_2000 y1lı (\%)

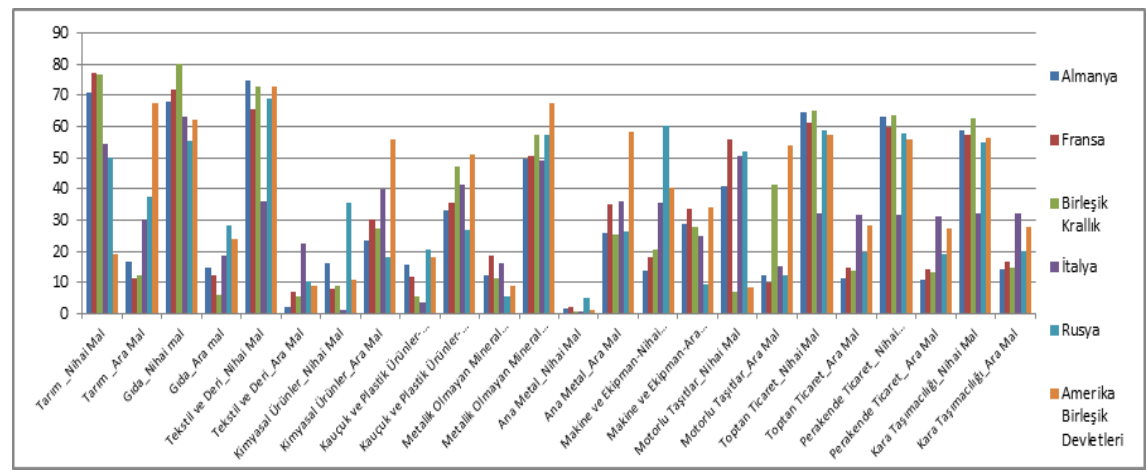

Kaynak: WIOD (2016) kullanılarak yazar tarafindan oluşturulmuştur.

Aşağıda yer verilen 7 numaralı grafikte, 2000 yılına kıyasla 2014 yilında hem nihai mal hem de ara mal ihracatında yurtiçi katma değerin azalmış olduğu sonucu yer almaktadır. Diğer yandan, Türkiye'nin nihai ve ara mal ihracatçısı olduğu sektörlerde değişiklik gerçekleşmemektedir.

\section{Grafik 7. İhracatta Ara Mal-Nihai Mal Ayrımı_2014 yılı (\%)}

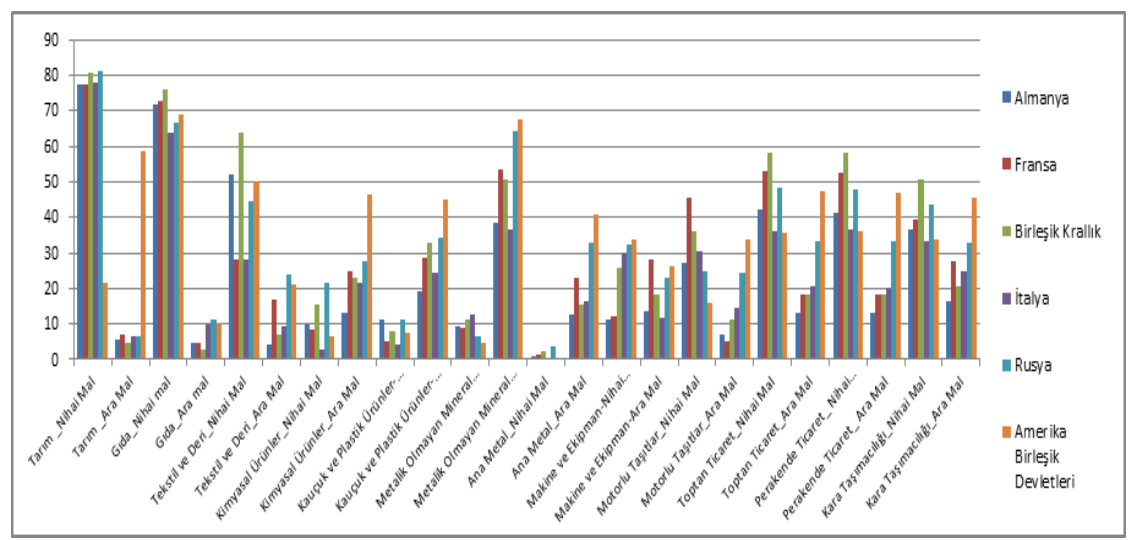

Kaynak: WIOD (2016) kullanılarak yazar tarafindan oluşturulmuştur.

Geliştirilen ayrıştrma metodunda yer alan 6, 7 ve 8 numaralı bileşenler toplanarak Türkiye'nin sektörel ihracatının ne kadarlık kısmının diğer ülkelerin ihracatları aracilığıyla ülkeye geri döndüğü hesaplanmaktadır. 8 numaralı grafikte, Türkiye'nin yaptığı ihracatın diğer ülkelerin ihracatları ile Türkiye'ye geri dönüş oranının düşük olduğuna yer verilmektedir. İmalat sanayi sektöründe geri dönüş oranı, tarım ve hizmetler sektörüne kıyasla daha yüksektir. Türkiye'den yapmış olduğu ithalatı, kendi ihracatı için kullanarak en çok ihracat yapan ülkeler ise Almanya ve İtalya'dır. 


\section{Grafik 8. Geri Dönen İhracat (\%)}

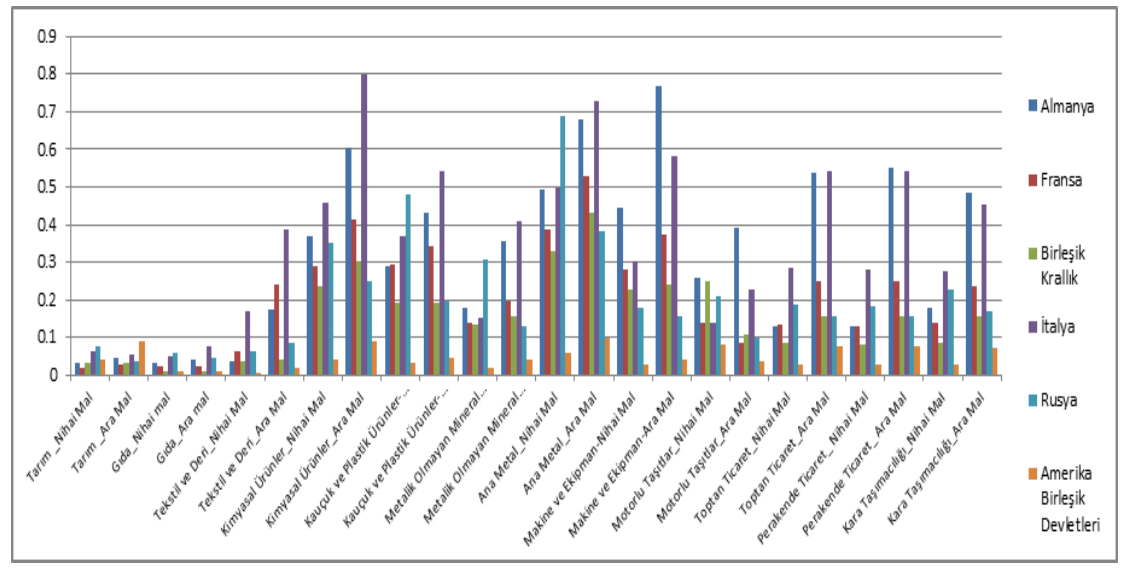

Kaynak: WIOD (2016) kullanılarak yazar tarafindan oluşturulmuştur.

Ayrıştırma metodunda yer alan 11 ve 12 numaralı bileşenler toplanarak nihai ihracattaki yabancı katma değer; 13 ve 14 numaralı bileşenler toplanarak ara mal ihracatındaki yabancı katma değer elde edilmektedir. Wang vd. (2013)'e göre, bir ülkenin nihai ihracatı ara mal ihracatına kıyasla daha çok yabanc1 katma değer içeriyorsa o ülke, küresel üretimin montaj aşamasındadır. Aksine bir ülkenin ara mal ihracatı daha yüksek yabancı katma değer içeriyorsa; o ülke, diğer ülkeler için ara mal üretme potansiyeline sahip olarak küresel değer zincirinin daha üst aşamasında olacaktır. Wang vd. (2013) çalışmasının tamamlayıcısı niteliğinde olan Dünya Bankası Raporu (2014), hammadde temini ya da üretimin araştırma, dizayn gibi maddi olmayan aşamalarında uzmanlaşan ülkenin üretime dönük; üretimin montaj işlemlerinde ya da müşteri hizmetleri gibi aşamalarında faaliyet gösteren ülkenin üretimin satışa dönük aşamasında uzmanlaşacağını ifade etmektedir. $\mathrm{Bu}$ rapora göre, üretimde satışa dönük aşamalarda faaliyet gösteren ülkeler, küresel değer zincirine katılımdan çok fazla fayda elde edemeyecektir.

9 numaralı grafikte yer alan sonuçlara bağlı olarak, Türkiye'nin ara mal ihracatçısı olduğu kimyasal ürünler, kauçuk ve plastik ürünler, metalik olmayan mineral ve ana metal sektöründe daha yüksek ithal girdi kullanması sebebiyle küresel değer zincirinin daha üst basamaklarında olduğu ve küresel değer zincirine katılımdan daha yüksek yarar sağlayacağı düşünülmektedir. 
Grafik 9 : Nihai-Ara Mal İhracatındaki Yabancı Katma Değer_2000 y1l1 (\%)

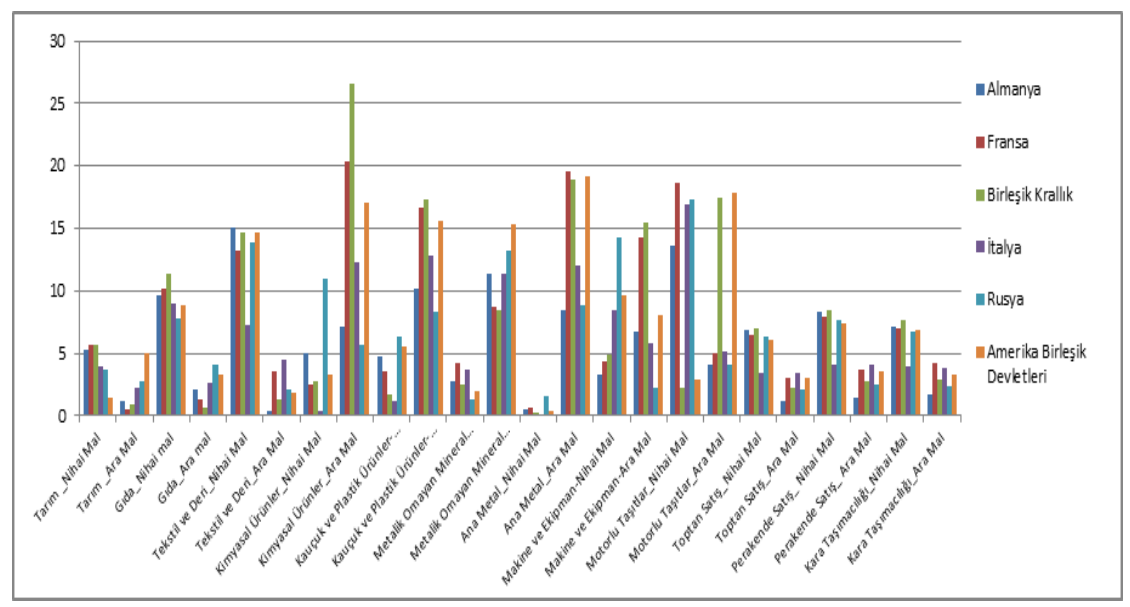

Kaynak: WIOD (2016) kullanılarak yazar tarafindan oluşturulmuştur.

Dünya Bankası Türkiye Raporu (2014:49-52) ve Taymaz (2011:91) çalışmasına paralel olarak; Türkiye, ihracat sepetinde payı yüksek olan tekstil, gıda ve makine sektörünün nihai ürün aşamasında rekabetçidir. 2000 yılı ile 2014 yılı karşılaştırıldığında, Türkiye’nin kimyasal ürünler sektöründe güç kaybettiği ve küresel değer zincirindeki konumunun gerilemeye başladığ1; metalik olmayan mineral ürünler ve ana metal sektöründe küresel değer zincirinin üst basamaklarındaki yerini koruduğu sonucuna ulaşılmaktadır.

Grafik 10. Nihai-Ara Mal İhracatındaki Yabancı Katma Değer_2014 y1l1 (\%)

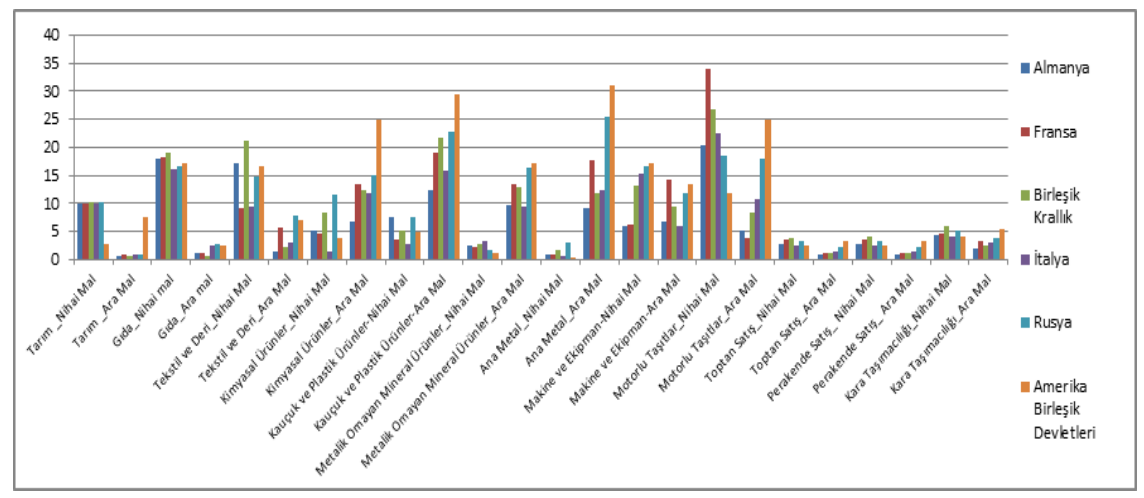

Kaynak: WIOD (2016) kullanılarak yazar tarafindan oluşturulmuştur.

Sonuç olarak, Türkiye küresel değer zincirine entegrasyonunu artırsa da ağırlıklı olarak emek yoğun aşamalarda üretim sürecine dahil olmaktadır. Ayrıca, Ziemann ve Guerard (2017:7)'in çalışmalarında yer verdiği gibi 
Türkiye yoğunluklu olarak nihai mal ihracatçısı konumundadır. Fakat ana metal, kauçuk ve plastik ürünler, metalik olmayan mineral, kimyasal ürünler gibi sektörlerde değer zincirinde konumunu yükseltebilmek için potansiyeli bulunmaktadır (Dünya Bankası, 2014).

\section{Sonuç ve Değerlendirme}

Çalışmada WIOD veri tabanı kullanılarak Türkiye'nin tarım, madencilik, imalat sanayi ve hizmetler sektöründe ikili ticaret bağlamında 43 ülkeye gerçekleştirdiği sektörel ihracattaki yurtiçi ve yabancı katma değer oranı analiz edilmektedir. Çalışmanın literatüre katkısı, 2000-2014 dönemlerini kapsayan analizin bütün sektörler için yapılarak Türkiye'nin sektörel ihracatındaki yurtiçi ve yabancı katma değer oranının analiz edilmesidir.

Çalışmanın sonuçları, küresel yeni iş bölümünde yaşanan dönüşüme uyum sağlayan ülkelerden birinin Türkiye olduğunu göstermektedir. Türkiye ekonomisinin büyük ölçüde ucuz emek yoğun olan üretimden daha sermaye yoğun üretime ve kurumsal üretime geçmesiyle ihracat sepeti büyük ölçüde değişmektedir. Metal, makine, gıda, kimyasal ürünler, kauçuk ve plastik ürün sektörlerinin ihracat sepetindeki ağırlığ1 artmaktadır.

2007-2013 yıllarını kapsayan 9. Kalkınma Planı'nda ithal bağımlılığını azaltıcı politikalara sık sık vurgu yapılmaktadır. Bu politikaların başarıya ulaşıp ulaşmadı̆̆ının tespiti için 2005-2014 yılları analiz edildiğinde hizmetler sektöründe ithal girdinin azaldığı sonucu elde edilmektedir. Aksine, ithal girdi bağımlılığı, tarım sektöründe az oranda da olsa artış göstermekte olup g1da sektöründe bu oran, daha yüksek gerçekleşmektedir. İmalat sanayi sektöründe ithal girdinin başarılı bir şekilde azaltıldı̆̆1 alt sektörler, ana metal, metalik olmayan mineral ürünlerdir. Makine ve ekipman, motorlu taşıtlar, kauçuk ve plastik ürünler alt sektörlerinde bağımlılı̆̆ın yüksek oranda arttı̆̆1 gözlemlenmektedir.

Her ne kadar Türkiye, küresel yeni iş bölümüne uyum sağlasa da sanayide teknolojik değişim ve yeniliği yeterli düzeyde temin etmediğinden küresel değer zincirinde, düşük katma değerli, ithal girdi oran1 yüksek, birim fiyatları düşük ürünler üreterek emek yoğun aşamalarda yer almaktadır. İthal girdiye bağımlı ve düşük teknolojili sektörlerde uzmanlaşan Türkiye, imalat sanayi yapısını dönüştürememekte, imalat sanayi sektöründe katma değeri azalmaktadır. Rekabet üstünlüklerinin azaldı̆̆1 sektörlerde uzmanlaşılması, ithal girdiye bağımlı olunması, hizmetler sektörünün giderek ağırlı̆̆ını artırdığ1 Türkiye'de sanayisizleşme sürecine girilmektedir. 9. Kalkınma Planı'nda yer verildiği üzere, rekabetçiliğin düşük olması, makroekonomik istikrarsılık, finansmana erişimde yaşanan sorunlar, enerji ve ulaştırma altyapısında yetersizlik, Ar-Ge ve yenilikçiliğin geliştirilmemesi, bilgi ve iletişim teknolojilerinin yeterince yaygınlaştırılmaması ile ilintilidir. 
2000-2014 y1lları kapsayan 15 yıllık dönemde birçok sektörde ihracattaki yurtiçi katma değer azalmakta ve ithal girdi kullanımının artışıyla yabancı katma değerde artış yaşanmaktadır. Sektör bazında değerlendirme yapıldığında; imalat sanayi sektöründe ithalat bağımlılı̆̆ın yüksek olduğu ve söz konusu dönemde de bu bağımlılı̆̆ının arttığ1 tespit edilmektedir. İhracatta en yüksek paya sahip olan imalat sanayi sektörü, ithal girdi kullanımında da ilk sıradadır. 2014 y1lında ithal girdi kullanımında artış meydana gelmektedir. Gelirdeki pay1 en yüksek olan hizmetler sektörü, imalat sanayi sektöründen sonra en yüksek ithal girdi kullanan ikinci sektördür. İthal girdinin en az kullanıldığ1 sektörler, tarım ve madenciliktir. İhracattaki yurtiçi katma değere alt sektör bazında bakıldığında; imalat sanayi sektörü içerisinde en yüksek pay tekstil ve deri, metalik olmayan mineral ürünler, makine ve ekipman ve ana metal sektörlerindedir. Yurtiçi katma değerde y1llar içerisinde en fazla düşüşün yaşandığ1 sektörler ise motorlu taşıtlar, ana metal ve kauçuk ve plastik ürünlerdir. Az oranda da olsa yurtiçi katma değeri yıllar içerisinde artan hizmetler sektöründe en yüksek katma değer, toptan ticaret, kara taşımacilığ1 ve perakende ticaret alt sektörlerindedir.

Türkiye, tarım, gıda, tekstil ve deri, makine ve ekipman, motorlu satışlar, toptan ve perakende ticaret ve kara taşımacılı̆̆ında nihai mal ihracatçısı iken kimyasal ürünler, kauçuk ve plastik ürünler, metalik olmayan mineral, ana metal imalat sanayi alt sektörlerinde ara mal ihracatçısıdır. Dolayısıyla Türkiye, kimyasal ürünler, kauçuk ve plastik ürünler, metalik olmayan mineral, ana metal imalat sanayi alt sektörlerinde küresel değer zincirinin üretime dönük aşamalarında dahil olarak değer zincirinde daha iyi konumlanmış durumdadır. Tarım, gıda, tekstil ve deri, makine ve ekipman, motorlu satışlar, toptan ve perakende ticaret ve kara taşımacılığında ise üretimin satışa dönük aşamalarında rol almaktadır. Diğer yandan, 2000 ile 2014 yılı karşılaştırıldığında, hem nihai mal hem de ara mal ihracatında yurtiçi katma değerin azaldığı tespit edilmektedir.

Yüksek katma değer yaratan aşamalara geçmek için ithal girdinin yoğun olarak kullanıldığı imalat sanayi sektöründe öncelikle bu bağımlılığ1 azaltacak politikalar uygulanmalıdır. Bu politikaların uygulanması, imalat sanayi sektöründe teknoloji üretiminin gelişmesi, modern teknoloji kullanımının yaygınlaşması, beşeri sermayenin temin edilmesi, yüksek katma değerli ürünlerde üretim kabiliyetinin artması, yeni gelişen sektörlere yatırım yapılmasını gerektirmektedir. Türkiye, kimyasal ürünler, kauçuk ve plastik ürünler, makine ve ekipman, motorlu taşıtlar ve ana metal sektöründe daha iyi konumdadır. Daha kaliteli ürünlere sahip olan sektörlerin ihracat pazarlarında varlıklarını sürdürmeleri daha olası olduğu için Türkiye'nin kalite standarlarının daha önemli olduğu makine ve ekipman, motorlu taşıtlar ve ana metal gibi sektörlerde birikimini kullanarak başka pazarlara açılabilme potansiyeli vardır. Toplam ihracatta payı yüksek olan tekstil sektöründe 
katma değeri yüksek ürünler üretilerek ve farklı pazarlara açlarak rekabetçi güç korunabilir. Gayrisafi yurtiçi hasıla içerisindeki payı \%60'ın üzerinde olan hizmetler sektöründe ise asıl sorun bu sektörün toplam ihracattaki payının çok düşük olmasıdır. Ekonomideki ağırllğı yüksek olan bu sektörde, katma değeri yüksek alt sektörlerin payının ve ihracatının artırılması, bilgi ve iletişim teknolojileri kullanımının yaygınlaştırılması gerekmektedir. Ulaştırma ve lojistik gibi önemli hizmetler sektörlerinin, ürün ve hizmet arzını zamanında, etkin ve uygun maliyetle karşılayabilmesine yönelik politikaların uygulanmasi gerekmektedir.

10. Kalkınma Planı'nda yer verildiği üzere, sanayisizleşme ile karşı karşıya kalınan Türkiye'de, imalat sanayi sektörü ile hem imalat sanayi alt sektörleri arasında hem de tarım ve hizmetler sektörleriyle değer zinciri bazlı bütünleşmenin artırlması gerekmektedir. Bilim, teknoloji ve yenilik politikalarının, eğitim, sanayi ve bölgesel politikalarla tamamlayıcı olarak yürütülmesi, sanayi sektörü yanında hizmetler ve tarım sektörlerinde katma değer artışı sağlanması ile uluslararası düzeyde rekabetçi ve yüksek katma değerli yeni sektörler, ürün ve markalar ortaya çıkarak Ar-Ge ve yenilik programları yürürlüğe geçebilecektir.

Sonuç olarak, Türkiye küresel değer zincirinde potansiyeli ile orantılı olarak yer almamaktadır. Türkiye'nin uluslararası rekabetçi gücünün artılarak küresel değer zincirine tam entegrasyonunun sağlanması için üretimde yurtiçi katma değerin yükseltilmesi, daha kaliteli mallar üretilerek ürün yelpazesinin küresel pazarda yüksek talep gören ürünleri kapsayacak şekilde genişletilerek teknoloji yoğunluklu hale getirilmesi gerekmektedir.

\section{EK}

Dış ticarette katma değer ya da dikey uzmanlaşma ile ilgili ayrıştırma metotlarının kökenlerinin Leontief (1936)'e dayanması sebebi ile Leontief ayrıştırma metodunun aşamalarının irdelenmesi önem arz etmektedir. Wang vd. (2013), iki ülkeden oluşan bir dünyada ülkelerin $\mathrm{N}$ farklı ürün ürettiğinin varsayıldığ bir örnekle Leontief ayrıştırma metodunu örnekle açıklamaktadır. Her sektördeki ürün ya tüketilmekte ya da ara girdi olarak kullanılmaktadır. Ayrıca her iki ülke de ara ve nihai mal ve hizmet ihraç etmektedir. S ülkesi tarafindan üretilen ürün yurtdışında ya da ülkede ara girdi ya da nihai ürün olarak tüketilmektedir.

$$
X^{s}=A^{s s} X^{s}+Y^{s s}+A^{s r} X^{r}+Y^{s r} \quad r, s=1,2
$$

Üstte (1) numaralı denklemde yer alan $X^{s}$, s ülkesinin Nx1 boyutlu çlktı (üretim) vektörünü, $Y^{s r}$, s ülkesi tarafindan üretilip r ülkesi tarafindan nihai talep olarak tüketilen $\mathrm{Nx} 1$ boyutlu nihai talep vektörünü ve $A^{s r}$, s ülkesinde üretilen mal ve hizmetlerin $\mathrm{r}$ ülkesi tarafindan ara girdi olarak kullanılan kısmını göstermekte olup $\mathrm{NxN}$ boyutlu girdi çıktı katsayı matrisi 
olarak ifade edilmektedir. İki ülkenin yer aldığ1 üretim ve ticaret sistemi (2) numaralı denklemden itibaren gösterilmektedir.

$$
\left[\begin{array}{l}
X^{s} \\
X^{r}
\end{array}\right]=\left[\begin{array}{ll}
A^{s s} & A^{s r} \\
A^{r s} & A^{r r}
\end{array}\right]\left[\begin{array}{l}
X^{s} \\
X^{r}
\end{array}\right]+\left[\begin{array}{l}
Y^{s s}+Y^{s r} \\
Y^{r s}+Y^{r r}
\end{array}\right]
$$

Gerekli düzenlemenin ardından Leontief ters matris matrisi oluşturulmaktadır.

$$
\left[\begin{array}{l}
X^{s} \\
X^{r}
\end{array}\right]=\left[\begin{array}{cc}
I-A^{s s} & -A^{s r} \\
-A^{r s} & I-A^{r r}
\end{array}\right]^{-1}\left[\begin{array}{l}
Y^{s s}+Y^{s r} \\
Y^{r s}+Y^{r r}
\end{array}\right]=\left[\begin{array}{ll}
B^{s s} & B^{s r} \\
B^{r s} & B^{r r}
\end{array}\right]\left[\begin{array}{l}
Y^{s} \\
Y^{r}
\end{array}\right]
$$

$\mathrm{NxN}$ blok matrisinden oluşan $B^{s r}$, Leontief ters matrisi olarak ifade edilmektedir. Leontief ters matris, toplam gereklilik matrisi olarak tanımlanmakta olup, $\mathrm{r}$ ülkesinin 1 birimlik nihai mal talep artışını karşılamak için s ülkesinin yapması gereken üretimin miktarını göstermektedir. Denklemde yer alan $Y^{s}$, s ülkesinin nihai ürününün küresel talebini $\left(Y^{s s}, \mathrm{~s}\right.$ ülkesinin yurtiçi nihai satışı ve $Y^{s r}$,s ülkesinin nihai ürün ihracatını tanımlamakta) ifade etmektedir.1 dolarlık ihracat yapmak için gerçekleştirilen üretimden elde edilen katma değer $\mathrm{V}$ olup elde edilen katma değer, direkt katma değer olarak ifade edilmektedir. İhracat yapmak için ara girdiler de kullanılmaktadır ve üretilen bu ara girdi dolaylı katma değer yaratmaktadır. Ara mal kullanıldıkça diğer ara girdilerinin de üretilmesiyle bu döngü devam etmektedir. 1 dolarlık ihracatın yaratmış olduğu katma değer, direkt ve bütün dolaylı katma değerlerin toplamına eşittir.

Toplam Katma Değer $=V+V A+V A A+V A A A \ldots=V\left(I+A+A^{2}+A^{3}+\right.$ $\cdots)=V(I-\mathrm{A})^{-1}=V B$

$V B$ vektöründe yer alan bütün bileşenler birdir.

$$
V B=\left[\begin{array}{ll}
V^{s} & V^{r}
\end{array}\right]\left[\begin{array}{ll}
B^{s s} & B^{s r} \\
B^{r s} & B^{r r}
\end{array}\right]=\left[\begin{array}{ll}
V^{s} B^{s s}+V^{r} B^{r s} & V^{s} B^{s r}+V^{r} B^{r r}
\end{array}\right]
$$

Yukarıdaki denklem, toplam katma değer katsayı matrisini göstermektedir.

Leontief ayrıştırma yöntemi, nihai nihai mal ihracatının yurtiçi ve yabancı katma değer olarak ayrıştırılmasına elverişli olmakla birlikte ara mal ihracatının ayrıştırılmasını bu ayrıştırma yöntemi ile gerçekleştirmek mümkün değildir. Wang vd. (2013), Leontief ayrıştırma yönteminden yola çıkarak ara malın ayrıştırıldığı bir yöntem geliştirmektedir. S ülkesinden r ülkesine yapılan brüt ihracat, $E^{s r}$, nihai mal ihracatı ve ara mal ihracat olarak ayrıştırılmaktadır.

$$
E^{s r}=Y^{s r}+A^{s r} X^{r}
$$

3 numaralı denklemin $G$ tane ülke olacak şekilde düzenlenmesinin ardından (6) numaralı denklemin sonuna eklenmesiyle s ülkesinin $r$ ülkesine olan ara mal ihracatı ayrıştırılmaktadır. 


$$
\begin{aligned}
& \quad A^{s r} X^{r}=A^{s r} B^{r r} Y^{r r}+A^{s r} \sum_{t \neq s, r}^{G} B^{r t} Y^{t t}+A^{s r} B^{r r} \sum_{t \neq s, r}^{G} Y^{r t}+ \\
& A^{s r} \sum_{t \neq s, r}^{G} B^{r t} \sum_{t \neq s, r}^{G} Y^{t u}+A^{s r} B^{r r} Y^{r s}+A^{s r} \sum_{t \neq s, r}^{G} B^{r t} Y^{t s}+ \\
& A^{s r} B^{r s} Y^{s s}+A^{s r} B^{r s} \sum_{t \neq s}^{G} Y^{s t}
\end{aligned}
$$

Denklemin birinci bileşeni s ülkesinin $\mathrm{r}$ ülkesine $\mathrm{r}$ ülkesinin nihai tüketimi için yapmış yaptığı ara mal ihracatını; ikinci bileşen s ülkesinin $\mathrm{r}$ ülkesine, üçüncü ülkelerin (t) nihai mal tüketimi için yapmış olduğu ara mal ihracat1 için, gerçekleştiği ara mal ihracatı; üçüncü bileşen $s$ ülkesinin $r$ ülkesine, üçüncü ülkelerin nihai mal tüketimi için yapmış olduğu nihai mal ihracatı için, gerçekleştiği ara mal ihracatı; dördüncü bileşen $s$ ülkesinin $r$ ülkesine, üçüncü ülkelerin $\mathrm{r}$ ülkesi dahil olmak üzere - $\mathrm{s}$ ülkesi hariç- diğer ülkelerin nihai mal tüketimi için yapmış olduğu nihai mal ihracatı sebebiyle gerçekleştirdiği ara mal ihracatı için, gerçekleştiği ara mal ihracatı; beşinci bileşen $\mathrm{s}$ ülkesinin $\mathrm{r}$ ülkesine, $\mathrm{s}$ ülkesine gerçekleştireceği nihai mal ihracatı için, yaptığı ara mal ihracatı; altıncı bileşen $s$ ülkesinin $r$ ülkesine, üçüncü ülkelerin $(\mathrm{t}) \mathrm{s}$ ülkesinin nihai mal tüketimi için yapmış olduğu nihai mal ihracatı sebebiyle gerçekleştirdiği ara mal ihracat için, gerçekleştiği ara mal ihracat1; yedinci bileşen $s$ ülkesinin $r$ ülkesine, $s$ ülkesinin kendi nihai mal tüketimini yapması için gerekli olan üretim için yapmış olduğu ara mal ihracatı için, gerçekleştiği ara mal ihracatı ve son bileşen $s$ ülkesinin $r$ ülkesine, s ülkesinin diğer ülkelerin nihai mal tüketimi için gerçekleştirdiği nihai mal ihracatı için, gerçekleștiği ara mal ihracatını tanımlamaktadır. Denklemde oluşturulan sekiz bileşen, $s$ ülkesinden $r$ ülkesine, nerede tüketildiğine bağlı olarak, gerçekleştirilen ara malı ihracatını göstermektedir.

(2) numaralı denklemden yola çıkılarak çıktı ve kullanım dengesi aşağıda yer alan denklemlerde olduğu gibi gösterilmektedir.

$$
\begin{aligned}
& X^{r}=A^{r r} X^{r}+\sum_{t \neq r}^{G} A^{r t} X^{t}+Y^{r r}+\sum_{t \neq r}^{G} Y^{r t} \\
& =A^{r r} X^{r}+Y^{r r}+\sum_{t \neq r}^{G} E^{r t}=A^{r r} X^{r}+Y^{r r}+E^{r^{*}} \\
& X^{r}=(I-\mathrm{A})^{-1} Y^{r r}+(I-\mathrm{A})^{-1} E^{r^{*}}=L^{r r} Y^{r r}+L^{r r} E^{r^{*}}
\end{aligned}
$$

Yukarıda yer alan $L^{r r},(I-\mathrm{A})^{-1}$ olarak gösterilmekte olup yerel Leontief ters matrisini ${ }^{3}$ ifade etmektedir.

(9) numaralı denklemin (6) numaralı denklemin sonuna eklenmesiyle s ülkesinin $\mathrm{r}$ ülkesine olan ara mal ihracatı iki bileşene ayrılmaktadır.

$$
A^{s r} X^{r}=A^{s r} L^{r r} Y^{r r}+A^{s r} L^{r r} E^{r^{*}}
$$

${ }^{3}$ Yerel Leontief matris yanda gösterildiği gibi elde edilmektedir: $L^{r r}=\left[\begin{array}{ll}l_{11}^{r r} & l_{12}^{r r} \\ l_{21}^{r r} & l_{22}^{r r}\end{array}\right]=$ $\left[\begin{array}{cc}1-a_{11}^{r r} & -a_{12}^{r r} \\ a_{21}^{r r} & 1-a_{22}^{r r}\end{array}\right]^{-1}$ 
(10) numaralı denklem, bir ülkenin çift taraflı ihracatındaki yabancı katma değerin farklı katma değer ve çifte sayım bileşenlerinin oluşturulma aşamasında kullanılmaktadır.

S ülkesinin $\mathrm{r}$ ülkesine olan ara mal ihracatını ifade eden (7) ve (10) numaralı denklemler, çift taraflı ihracatın ayrıştırılmasının bir adımını oluşturmaktadır. Wang vd. (2013) tarafından geliştirilen ayrıştırma metodunda, bu iki denklem genellikle içsel olan çıktı ve ihracatı dişsal değişkene dönüştürmektedir. Ayrıştırma metodunun inşası için ayrıca küresel katma değer çarpanı olarak ifade edilen (5) numaralı denklem $G$ ülkeli forma dönüştürülerek yurtiçi ve yabancı katma değer çarpanları elde edilmektedir.

$$
V^{s} B^{s s}+V^{r} B^{r s}+\sum_{t \neq s, r}^{G} V^{t} B^{t s}=u
$$

$\mathrm{S}$ ülkesinin $\mathrm{r}$ ülkesine nihai mal ihracatı, Leontief ayrıştırma metodu kullanılarak yurtiçi ve yabancı katma değer olmak üzere sektör düzeyinde iki ayrı bileşene ayrılmaktadır.

$$
Y^{s r}=\left(V^{s} B^{s s}\right)^{T} \# Y^{s r}+\left(V^{r} B^{r s}\right)^{T} \# Y^{s r}+\left(\sum_{t \neq s, r}^{G} V^{t} B^{t s}\right)^{T} \# Y^{s r}
$$

Aynı şekilde, s ülkesinin r ülkesine yapmış olduğu brüt ihracat sektör düzeyinde ayrıştırılmaktadır.

$$
\begin{aligned}
& A^{s r} X^{r}=\left(V^{s} B^{s s}\right)^{T} \#\left(A^{s r} X^{r}\right)+\left(V^{r} B^{r s}\right)^{T} \#\left(A^{s r} X^{r}\right)+\left(\sum_{t \neq s, r}^{G} V^{t} B^{t s}\right)^{T} \#\left(A^{s r} X^{r}\right) \\
& =\left(V^{s} L^{s s}\right)^{T} \#\left(A^{s r} X^{r}\right)+\left(V^{s} B^{s s}-V^{s} L^{s s}\right)^{T} \#\left(A^{s r} X^{r}\right)+\left(V^{r} B^{r s}\right)^{T} \#\left(A^{s r} X^{r}\right)+ \\
& \left(\sum_{t \neq s, r}^{G} V^{t} B^{t s}\right)^{T} \#\left(A^{s r} X^{r}\right)
\end{aligned}
$$

Denklemde yer alan $V^{S} L^{S S}$ yurtiçi katma değer çarpanını göstermektedir.

Wang vd. (2013), (7) numaralı denklemi (13) numaralı denklemin ilk bileşenine, (10) numaralı denklemi de (13) numaralı denklemin son iki bileşenine ekledikten sonra (12) ve (13) numaralı denklemi birleştirerek s ülkesinin r ülkesine yaptığı brüt ihracatı (14) numaralı denklemde olduğu gibi ayrıştırmaktadir.

$$
\begin{aligned}
& E^{s r}=\left(V^{s} B^{s s}\right)^{T} \# Y^{s r}+\left(V^{s} L^{s s}\right)^{T} \#\left(A^{s r} B^{r r} Y^{r r}\right) \\
& +\left(V^{s} L^{s s}\right)^{T} \#\left[A^{s r} \sum_{t \neq s, r}^{G} B^{r t} Y^{t t}+A^{s r} B^{r r} \sum_{t \neq s, r}^{G} Y^{r t}+A^{s r} \sum_{t \neq s, r}^{G} B^{r t} \sum_{u \neq s, t}^{G} Y^{t u}\right] \\
& +\left(V^{s} L^{s s}\right)^{T} \#\left[A^{s r} B^{r r} Y^{r s}+A^{s r} \sum_{t \neq s, r}^{G} B^{r t} Y^{t s}+A^{s r} B^{r s} Y^{s s}\right] \\
& \left.+\left[\left(V^{s} L^{s s}\right)^{T} \# A^{s r} B^{r s} \sum_{t \neq s}^{G} Y^{s t}\right)+\left(V^{s} L^{s s} \sum_{t \neq s}^{G} A^{s t} B^{t s}\right)^{T} \#\left(A^{s r} X^{r}\right)\right] \\
& +\left[\left(V^{r} B^{r s}\right)^{T} \# Y^{s r}+\left(\sum_{t \neq s, r}^{G} V^{t} B^{t s}\right)^{T} \# Y^{s r}\right] \\
& +\left[\left(V^{r} B^{r s}\right)^{T} \#\left(A^{s r} L^{r r} Y^{r r}\right)+\left(\sum_{t \neq s, r}^{G} V^{t} B^{t s}\right)^{T} \#\left(A^{s r} L^{r r} Y^{r r}\right)\right] \\
& {\left[\left(V^{r} B^{r s}\right)^{T} \#\left(A^{s r} L^{r r} E^{r^{*}}\right)+\left(\sum_{t \neq s, r}^{G} V^{t} B^{t s}\right)^{T} \#\left(A^{s r} L^{r r} E^{r^{*}}\right)\right]}
\end{aligned}
$$




\section{Kaynakça}

Akkoyunlu, A.W S.Mıhçı \&K. Ataç (2018). Türkiye imalat sanayi sektörlerinin küresel değer zincirleri içerisindeki konumu ve rekabet gücü: 2000-2011. N.Engin, E.Arslanoğlu, o. Erdoğan, B.C.Karahasan ve K.Tata (Ed.) Türkiye Ekonomisinde Kalkinma ve Dönüşüm içinde (s. 214-249).

Daudin, G., Rifflart, C., \& Schweisguth, D. (2011). Who produces for whom in the world economy?. Canadian Journal of Economics/Revue canadienne d'économique, 44(4), 14031437.https://doi.org/10.1111/j.1540-5982.2011.01679.

Dünya Kalkınma 2020 Raporu (2019). Global Value Chains: Trading for Development.http://pubdocs.worldbank.org/en/12468154817593 8170/World-Development-Report-2020-Concept-Note.pdf

Eser, U. (2019). Sanayi Politikası Olarak Meta Zincirleri ya da Meta Zincirleri Üzerinde Sanayisizleşmek. İktisat ve Toplum, 100: 67-80.

Feenstra, R. C., Hanson, G. H. (1996). Globalization, outsourcing, and wage inequality. (No. w5424). National Bureau of Economic Research. doi:10.3386/w5424.

Gündoğdu, C., Saracoğlu, D. Ş. (2016). Participation of Turkey in Global Value Chains: An Analysis Based on World Input Output Database.Economic Research Center.http://erc.metu.edu.tr/en/system/files/menu/series16/161 0 .pdf.

Hummels, D., Ishii, J., \& Yi, K. M. (2001). The nature and growth of vertical specialization in world trade. Journal of international Economics, 54(1):75-96.https://doi.org/10.1016/S00221996(00)00093-3.

Johnson, R. C., Noguera, G. (2012). Accounting for intermediates: Production sharing and trade in value added.Journal of international Economics, 86(2): 236.https://doi.org/10.1016/j.jinteco.2011.10.003.

Kalkınma Bakanlığ1 (2006),Dokuzuncu Kalkınma Planı (2007-2013). Sanayi Politikalar1 Özel İhtisas Komiyonu Raporu.http://www3.kalkinma.gov.tr/DocObjects/Download/35 77/oik676.pdf

Kalkınma Bakanlığ1 (2014), Onuncu Kalkınma Planı (2014-2018). İmalat Sanayiinde Dönüşüm Özel İhtisas Komisyonu Raporu.http://www.sbb.gov.tr/wpcontent/uploads/2018/10/10_ImalatSanayiindeDonusum.pdf 
Koopman, R., Wang, Z., \& Wei, S. J. (2014).Tracing value-added and double counting in gross exports. American Economic Review, 104(2): 45994.doi: $10.1257 /$ aer.104.2.459.

Leontief, W. W. (1936). Quantitative input and output relations in the economic systems of the United States. The review of economic statistics, 105-125.https://www.jstor.org/stable/1927837.

OECD (2017), International trade, foreign direct investment and global value chains. Trade and investment statistical note : Turkey.http://www.oecd.org/investment/TURKEY-tradeinvestment-statistical-country-note.pdf

Özmen, E. (2015).Türkiye'de cari açıllar, diş ticaret ve finansal kırılganlıklar.Iktisat, Isletme ve Finans Dergisi, cilt 30, sayı 351:35-72.

Sayg11ı, Ş, C.Cihan, C.Yalçın \& T.Hamsici (2014).Türkiye İmalat Sanayiinde Ithal Girdi Kullanımındaki Artışın Kaynakları.Iktisat, Issletme ve Finans Dergisi, cilt 29, say1 342:9-44.

Taymaz, E., E. Voyvoda, and K. Yilmaz (2011). Uluslararas1 Üretim Zincirlerinde Dönüşüm ve Türkiye'nin Konumu. TÜSİAD-Koç Üniversitesi EAF Çalışma Raporları Serisi EAFRP/11-01.

The World Bank (2014).Trading Up to High Income (Turkey Country Economic Memorandum).Poverty Reduction and Economic Management Unit, the World Bank.http://documents. worldbank.org/curated/en/924601468121739356/TurkeyTrading-up-to-high-income-country-economic-memorandum

UNCTAD (2016). Trade and Development Report. Structural transformation for inclusive and sustained growth.

https://unctad.org/en/PublicationsLibrary/tdr2016_en.pdf

Wang, Z., Wei, S. J., \& Zhu, K. (2013). Quantifying international production sharing at the bilateral and sector levels.(No. w19677). National Bureau of Economic Research.doi:10.3386/w19677

WIOD (2016). World Input Output Database. http://www.wiod.org

Ziemann, V., Guerard, B. (2017). Reaping the benefits of global value chains in Turkey.OECD Economics Department Working Papers, No. 1366, Paris: OECD Publishing. 